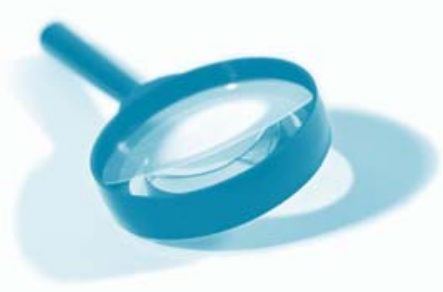

Nancy El-Farargy

NHS Education for Scotland

Thistle House

91 Haymarket Terrace

Edinburgh EH12 5HE

nfarar@gmail.com

The literature review is the informative, evaluative and critical synthesis of a particular topic and provides readers with a clear picture of the subject and its associated range of perspectives and opposing views.

\title{
Educational research: reviewing the literature
}

\begin{abstract}
As educators, we are often concerned with maximising learning experiences and in exploring or understanding the factors that may contribute to successful educational endeavours. Much of this may transcend into educational research, in which the literature review will be the essential component in clarifying what is already known about the topic and in documenting any unanswered questions to take the research forward. This process will often scope concepts and theories, research methods and strategies, significant controversies, and inconsistencies in findings related to the area. The literature review is the informative, evaluative and critical synthesis of a particular topic and provides readers with a clear picture of the subject and its associated range of perspectives and opposing views. In most cases, they are invaluable to readers because they collect evidence from a variety of sources that is evaluated and synthesised into a readable format.
\end{abstract}

This paper provides a narrative overview of the concepts and practices of literature searching for new educational researchers within physical sciences. A guidance checklist to searching the literature and a list of suggested publication outlets is also listed.

\section{Introduction}

There are numerous areas of foci within educational research, however in the main, we are often concerned with maximising learning experiences and in exploring factors that may contribute to 'success' in education. Such educational enquiry aligns the teaching profession with research-based professions, which uses evidence to inform practice. Formal educational research may be daunting to those embarking in the area for the first time, but in reality we are already used to watching ${ }^{1}$ processes, gathering information, questioning, making decisions, and in developing what we already know into new ideas and concepts - that are often extended into creating new products and in delivering new services.

Formal research extends and turns the processes of:

1. watching into observation, data gathering and systematic recording

2. asking questions into interviewing and distributing questionnaires

3. decision making into evaluating, critiquing and providing solutions to problems or in creating new policies 
Table 1: Categories of research ${ }^{1,2,3}$.

\begin{tabular}{|l|l|}
\hline \multicolumn{1}{|c|}{ Category } & \multicolumn{1}{c|}{ Description } \\
\hline Pure or basic research & $\begin{array}{l}\text { The development of theory, discovery and generation of fundamental facts to extend the } \\
\text { boundaries of knowledge. }\end{array}$ \\
\hline Applied research & $\begin{array}{l}\text { The application of new knowledge to solve everyday problems. Whilst more practical and } \\
\text { focuses on real world questions and applications, it employs the same rigorous methodology as } \\
\text { pure research. }\end{array}$ \\
\hline Action research & $\begin{array}{l}\text { Research undertaken locally by practitioners (in the workplace) to solve clearly identified } \\
\text { problems. }\end{array}$ \\
\hline Evaluation research & $\begin{array}{l}\text { In addition to determining whether original aims of specific projects and interventions have been } \\
\text { achieved, this research also assesses its effectiveness, merit and worth. }\end{array}$ \\
\hline
\end{tabular}

Hence, formal educational research is carried out in a more systematic, rigorous and deliberate ${ }^{1}$ manner that is often presented to the political, practical or academic worlds. The domain in which the work will be presented and applied to, supports the identification of the type and category of research to undertake (Table 1).

The literature suggests various definitions of research ${ }^{1,2,4,5,6,7}$, but on the whole they may encompass the following

methodologies and characteristics:

1. contextual reasons why issues or problems need to be addressed

2. rigorous and systematic approaches to addressing such problems

3. critical assimilation or synthesis of the literature that gives rise to a new school of thought

4. valid and verifiable approaches to data collection (e.g. through empirical means)

5. outputs contribute to the knowledge base

6. outputs contribute to the development of new techniques, ideas or approaches (e.g. organisational policy and change)

7. uses existing knowledge in a new and creative way to generate new concepts, methodologies and understandings

In looking at the nature of enquiry and in considering epistemology, research can be further divided into two paradigms $^{8}$ :

1. positivist $^{9}$ (quantitative)

2. interpretivist $^{10}$ (qualitative)

The positivist paradigm aligns itself with advances in the physical sciences, such that the 'scientific methodology' and thus objective analyses result in repeatable outcomes - when the same conditions are adhered to. This experimental approach consists of a hypothesis, and often involves large scale samples of control and experimental groups. "A positivist attempts to discover the laws that he thinks govern the relationships between 'causes' and 'effects' "8 and notes that a more objective stance needs to be maintained. In the realm of accumulating scientific knowledge however, original theories suggested can often be reinterpreted in light of new, original, and valid empirical evidence ${ }^{3,11}$.
On the other hand, the interpretivist paradigm aligns itself with the social world and its interactions. Thus the qualitative educational researcher is more involved in the interpretation of specified problems ${ }^{8}$ :

1. "qualitative research is an attempt to capture the sense that lies within, and that structures what we say about what we do

2. an exploration, elaboration and systemisation of the significance of an identified phenomenon

3. the illuminative representation of the meaning of a delimited issue or problem"

Subsets of qualitative research include ${ }^{12}$

1. grounded theory: data is gathered and analysed, and the theory is formed from that data ${ }^{13}$ (contrast this with data collection to test a theory)

2. ethnography: the researcher participates in peoples' lives (without structuring the environment) through a long period of observation ${ }^{1,14}$

3. phenomenography: an empirical approach, based on observation and experience, that aims to identify the qualitatively different ways in which people experience, conceptualise, perceive and understand different phenomena $^{15,16,17,18}$

There are a number of points to note when reviewing qualitative and quantitative work ${ }^{1}$. Empirical data - and the resulting statistical analyses - may not report or reveal underlying reasons; and such work may need to be backed up with rich narratives ${ }^{19}$ or other qualitative data ${ }^{12,20}$. In addition, a positive value for a correlation coefficient does not necessarily imply that there is a cause and effect relationship between measurements ${ }^{21}$ - explanations may also need to be sought. It has also been suggested that the way quantitative data is presented, categorised and analysed may be partly subject to researchers' understandings ${ }^{1}$ - thus this notion should not be neglected when interpreting such work. 


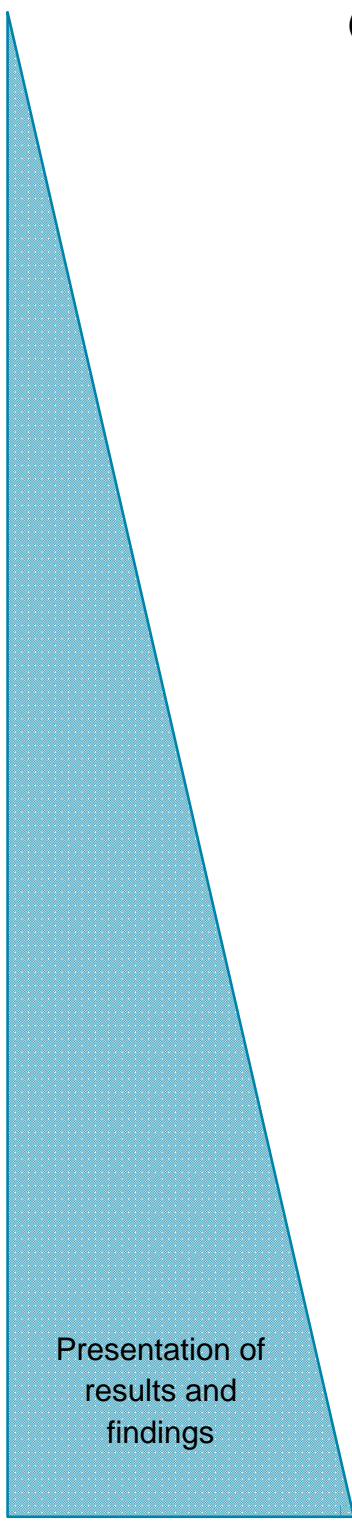

(1) Identify the topic of interest or the area of work that needs attending to.

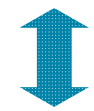

(2) Generate focussed questions.

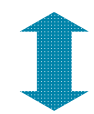

(3) State the hypothesis or unsolved problem and confirm gaps in the body of knowledge.

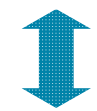

(4) Design data collection methodologies and obtain ethical approval*.

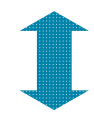

(5) Collect data and analyse.

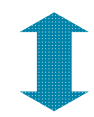

(6) Document results, contextualise findings and suggest solutions.

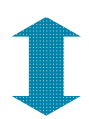

(7) Present results and solutions for potential implementation into policy or practice.

Figure 1: Educational research process hierarchy. Devising a Gantt chart at the earliest stage will help manage timescales and project delivery. *Ethical approval may be required earlier in the process; however, this is the most common stage of approval across the majority of institutions.

\section{The Literature Review}

In conducting research, the literature search and review process is an essential component. It offers readers with information about a particular topic, uncovers gaps that require further research and serves as a guide for the development of evidence-based practice. It can also support the requirements of a PhD research proposal or for obtaining research funding. Other fundamental reasons for undertaking a literature review include:

1. clarity and focus to the research problem

2. insight into research methodologies

3. contextual understanding of results and findings

4. whether the work has been previously thoroughly explored

5. how the current work proposal differs from the work of others
The search and review process begins with the identification of the topic of interest, through to generating the narrow research focus and in stating the current trends, unsolved problems and gaps in the body of knowledge. A natural progression occurs during the life of a research project: the amount of time spent on the literature review diminishes, as the focus increases on the generation and analysis of results, through to articulating and suggesting potential solutions. However, stages may be repeating in nature as one narrows and refines the focus of the project $^{22}$. The following diagram illustrates these concepts (Figure 1).

The subsequent paragraphs discuss stages 1-3 in more detail. 


\section{Topic of interest}

A general search of the literature will aid topic refinement and selection, and experienced supervisors will be able to signpost new research students to accessible published research. At this stage, it is imperative that all citations are recorded into a reference management system, (e.g. Zotero, EndNote, Reference Manager, Refworks and the like), such that a bibliographic trail is recorded. A general initial search of the literature may simply involve searching through databases, journals and abstracts, in which a list of useful references is drawn up. Checking reference lists in recent papers, until relevant citations are identified, is another method to initial searching.

Initial reading of abstracts will help shortlist references. In reading and summarising resources, a theoretical framework of common themes will be devised. In converting these themes into sub-headings, the main findings, questions and arguments can then be written up. Thereafter, a more focussed and detailed search will be required, and is normally initiated through the generation of research questions.

\section{The research questions}

At this stage, the research questions and objectives will have been clarified and thus a more rigorous search of the literature will be required. In addition, reasons for excluding certain data sets and studies will be become apparent. References can also be limited to certain time periods, e.g. the most recent articles; however, the disadvantage of narrowing the scope of the search may result in older relevant reviews being omitted.

\section{Source types}

In most cases a literature review will include resources from various types of written pieces, and it may be useful to categorise work as either research, descriptive or review. Opinion pieces usually consist of editorials and it will be up to the reviewer whether to include these. Depending on the nature and requirements of the review, a variety of sources ${ }^{23}$ may be used, or alternatively the review may consist of solely secondary and tertiary resources (Table 2 ).
Work that is not published in academic journals or indexed in databases is often given the term 'grey literature, ${ }^{, 4}$. This large volume of literature includes poster presentations, dissertations, newsletters, census data, government leaflets, corporate documents and committee reports. In the main, these are usually rapidly disseminated non-commercial resources that may often be related to emerging technologies and new policies. It is therefore important that such work is not wholly excluded and is evaluated as necessary.

\section{Types of literature reviews}

The narrative review attempts to (most commonly) synthesise the primary or secondary literature and to explore the heterogeneity within it; it continues to be an important vehicle for academic discussion, though it is noted that the technique can rely on the reviewers' judgement when reconciling conflicting results ${ }^{25}$. In this light, concentrating on the use of primary literature may help in maintaining accuracy when reporting. Overall, a narrative review helps form an initial impression of the general topic area and is often a discovery process.

As an alternative to the narrative review, a more systematic ${ }^{26}$ approach to the identification and use of educational literature may often be required. Systematic reviews attempt to collate and appraise the best available research to answer a specified question, and are completed by synthesising the results of several studies. Systematic reviews are resource intensive and usually require a team of researchers working collaboratively on the topic. Systematic reviews have ${ }^{27}$ :

1. clear inclusion/exclusion criteria

2. an explicit search strategy

3. systematic coding and analysis of included studies

4. meta-analysis (as applicable - quantitative studies and variable effect)

5. meta-ethnography (as applicable - qualitative studies)

Table 2: Depending on the scope of the literature review, sources of information can include primary (original), secondary (e.g. research syntheses) and tertiary materials (e.g. textbooks).

\begin{tabular}{|c|c|}
\hline Resources & $\begin{array}{l}\text { Books, journal articles, government reports, policy documents, theses and } \\
\text { dissertations, briefing papers, databases (collection of abstracts), conference } \\
\text { papers. }\end{array}$ \\
\hline \multirow{3}{*}{ Resource Type } & $\begin{array}{l}\text { Primary: original, first hand documents and pieces of evidence that are reported } \\
\text { by those who gathered the information. Examples include raw research } \\
\text { data, lab notebooks, parliamentary acts, charters, strategies, emails and } \\
\text { other correspondence, and proceedings of meetings etc. }\end{array}$ \\
\hline & $\begin{array}{l}\text { Secondary: non original materials based on primary sources that are reported } \\
\text { by the same authors or other authors (who have not been involved in the } \\
\text { generation of original data). Examples include research syntheses, reviews, } \\
\text { summaries, newspaper reports, and textbooks etc. }\end{array}$ \\
\hline & $\begin{array}{l}\text { Tertiary: non original materials that include distillations of secondary sources. } \\
\text { Examples include encyclopaedias, fact books, manuals, guidebooks, and } \\
\text { catalogues etc. These may be useful for those starting out in research for } \\
\text { the first time, but may not be strong enough to use as evidence for original } \\
\text { primary research. }\end{array}$ \\
\hline
\end{tabular}


Other criteria such as an international focus and a peer review policy are also commonly employed. In addition, an audit trail of the reviewers' conclusions will be made evident. The Campbell Collaboration Library of Systematic Reviews ${ }^{27}$ is a growing international research network that prepares, maintains and disseminates systematic reviews in education (and other fields). There is of course the well-established Education Resources Information Center (ERIC) database ${ }^{28}$ that signposts to over 1.4 million learning resources in education.

\section{Sources of information}

Numerous sources of educational information are available online and depending on the nature of the review, use of specific sources should be made clear at the outset. A suggested sample of website resources is shown in Table 3. In using general search engines, it is important to consider evaluating website search results. Consider for instance the motive of websites, the institution and general update dates.

Table 3: Some suggested sources of information for educational research. These include resources categorised under the following: (1) educational databases and collections of abstracts, (2) educational publishers and general links, (3) evidence gathering and systematic reviews, (4) general publishers and search software vendors, and (5) miscellaneous resources and grey literature resources. Note that this list is by no means exhaustive. (Links accessed 2012.) (Continued...)

\begin{tabular}{|l|l|}
\hline Resource and URL & Description \\
\hline \multicolumn{2}{|c|}{ Educational Databases and Collections of Abstracts }
\end{tabular}

Databases are usually the most abundant of resources; and are usually well indexed with descriptors and/or subject headings to help source the information required. Searching multiple databases will help ensure that significant evidence is not omitted. Note: most databases are accessible via organisational subscription, and/or searchable via subscribed search vendors (see below).

\begin{tabular}{l|l}
\hline Australian Education Index (AEI): & The Australian Council for Educational Research provides the
\end{tabular}

www.acer.edu.au/library/aei Australian Education Index (AEI). The AEl is a subscription database, currently consisting of more than 130,000 entries relating to educational research, policy and practice.

British Education Index (BEI):

The British Education Index (BEl) is accessed through

www.leeds.ac.uk/bei/index.html subscription and indexes content of significant education journals published within the UK. Currently, there are over 175,000 references to journal articles.

Education Resources Information Center (ERIC):

The Education Resources Information Centre (ERIC) is the

www.eric.ed.gov/ world's largest database (currently containing over 1.4 million bibliographic records). It is freely available on the internet and signposts to full text where available. ERIC is sponsored by the Institute of Education Sciences of the US Department of Education.

International Education Research Database (IERD):

research.ibo.org/pls/apex/f?

Initiated in 2002, the International Education Research

$p=107: 1: 1187941422610296:: N O:::$

Database (IERD) is a growing online resource for teachers and educators involved in all aspects of research in international education.

QAA Higher Education Empirical Research Database:

heerd.qaa.ac.uk/

This database comprises summaries of evidence-based published research on a range of topics related to higher education. Currently owned and managed by the Quality Assurance Agency (QAA) for Higher Education, it is intended for use by policy makers, academics and researchers in Higher Education.

Taylor and Francis Journals - Educational Research Abstracts (ERA) Online:

Educational Research Abstracts (ERA) online is a database that covers international educational research. With currently over 700 journals scanned, the database is aimed at researchers, www.tandf.co.uk/journals/titles/14675900.asp practitioners, academics and students within education.

Educational Publishers and General Education Links

Routledge Education Arena:

www.educationarena.com/ Routledge Education:

www.routledge.com/education/

Sage Publications Education:

www.uk.sagepub.com/education.nav
A general portal offering news, updates and journal links in education, as published by Routledge.

A general portal signposting to educational text and journals published by Routledge.

A general portal signposting to educational texts published by Sage. 
Table 3: (Continued...) Some suggested sources of information for educational research. These include resources categorised under the following: (1) educational databases and collections of abstracts, (2) educational publishers and general links, (3) evidence gathering and systematic reviews, (4) general publishers and search software vendors, and (5) miscellaneous resources and grey literature resources. Note that this list is by no means exhaustive. (Links accessed 2012.)

\begin{tabular}{|c|c|c|}
\hline Resource and URL Description & Den \\
\hline \multicolumn{2}{|c|}{ Evidence Gathering and Systematic Reviews }
\end{tabular}

This list highlights some resources that aim to collate the best evidence available within Education. These resources usually aim to answer a specific question within the field.

Best Evidence Encyclopedia (BEE):

www.bestevidence.org

Focussing mainly on primary and secondary education, the Best Evidence Encyclopedia (BEE) presents reviews of research-proven educational programs. It supports policy makers, teachers and researchers.

Cochrane Developmental, Psychosocial and Learning Problems Group (CDPLPG):

http://dplpg.cochrane.org

Danish Clearing House for Educational Research:

http://www.dpu.dk/en/aboutdpu/

danishclearinghouseforeducationalresearch/ evidencebase/

The Campbell Collaboration Library for Systematic Reviews:

The Cochrane Developmental, Psychosocial and Learning Problems Group (CDPLPG) uses Cochrane systematic review methodology to investigate topics that include educational and social interventions.

www.campbellcollaboration.org

The Evidence for Policy and Practice Information and Coordinating (EPPI) Centre:

http://eppi.ioe.ac.uk/cms/

Produced by a number of different organisations worldwide, the International Evidence Base is a database of systematic reviews in the field of education.

The Campbell Collaboration (C2) prepares, maintains and disseminates systematic reviews, including topics within education.

What Works Clearing House:

http://ies.ed.gov/ncee/wwc/

The Evidence for Policy and Practice Information and Coordinating (EPPI) Centre conducts systematic reviews and maintains an evidence library of reviews in the field of education (and other subjects).

Created in 2002 by the US Department of Education's Institute of Education Sciences, the What Works Clearing House aims to provide scientific evidence for 'what works' in education. 
Table 3: (Continued...) Some suggested sources of information for educational research. These include resources categorised under the following: (1) educational databases and collections of abstracts, (2) educational publishers and general links, (3) evidence gathering and systematic reviews, (4) general publishers and search software vendors, and (5) miscellaneous resources and grey literature resources. Note that this list is by no means exhaustive. (Links accessed 2012.)

\section{General Publishers and Search Software Vendors}

This list offers a collection of major publisher websites and search software vendors.

\begin{tabular}{|c|c|}
\hline $\begin{array}{l}\text { Cambridge Journals Online (Cambridge Universi- } \\
\text { ty Press): } \\
\text { journals.cambridge.org/ }\end{array}$ & $\begin{array}{l}\text { A collection of subscription journals published by Cambridge } \\
\text { University Press. }\end{array}$ \\
\hline $\begin{array}{l}\text { EBSCO: } \\
\text { search.ebscohost.com/ }\end{array}$ & $\begin{array}{l}\text { Available through subscription, EBSCO searches institutionally } \\
\text { subscribed databases that signpost to online journals and books. Full } \\
\text { text is available as per organisational subscriptions. }\end{array}$ \\
\hline $\begin{array}{l}\text { Emerald: } \\
\text { www.emeraldinsight.com/ }\end{array}$ & $\begin{array}{l}\text { Emerald hosts journals and books and offers the ability to search } \\
\text { bibliographic databases (subscribed content). }\end{array}$ \\
\hline $\begin{array}{l}\text { Ingentaconnect: } \\
\text { www.ingentaconnect.com/ }\end{array}$ & A search network that distributes content from over 250 publishers. \\
\hline $\begin{array}{l}\text { JSTOR: } \\
\text { www.jstor.org/ }\end{array}$ & $\begin{array}{l}\text { JSTOR is a search service that distributes mainly primary academic } \\
\text { content. }\end{array}$ \\
\hline $\begin{array}{l}\text { Ovid: } \\
\text { ovidsp.ovid.com/ }\end{array}$ & $\begin{array}{l}\text { Available through subscription, Ovid is a powerful search tool that } \\
\text { signposts to online journals, books and databases. Full text available } \\
\text { is usually available via institutional subscription. }\end{array}$ \\
\hline $\begin{array}{l}\text { ProQuest: } \\
\text { proquest.umi.com/login }\end{array}$ & $\begin{array}{l}\text { ProQuest is a search service that distributes content originally } \\
\text { published in magazines and journals. }\end{array}$ \\
\hline $\begin{array}{l}\text { Sage Journals Online: } \\
\text { online.sagepub.com/ }\end{array}$ & A collection of subscription journals published by Sage. \\
\hline $\begin{array}{l}\text { ScienceDirect: } \\
\text { www.sciencedirect.com/ }\end{array}$ & $\begin{array}{l}\text { ScienceDirect (Elsevier) is a scientific database that contains more } \\
\text { than } 10 \text { million journal articles and book chapters. }\end{array}$ \\
\hline $\begin{array}{l}\text { Taylor and Francis Journals: } \\
\text { www.tandf.co.uk/journals/ }\end{array}$ & $\begin{array}{l}\text { Taylor and Francis online provides access to, and information about, } \\
\text { all journals from Taylor and Francis, Routledge and Psychology } \\
\text { Press. }\end{array}$ \\
\hline $\begin{array}{l}\text { Web of science } ® / \text { Web of knowledge: } \\
\text { www.webofknowledge.com }\end{array}$ & $\begin{array}{l}\text { A subscription search tool that signposts to multidisciplinary citation } \\
\text { databases that includes the sciences and social sciences. }\end{array}$ \\
\hline $\begin{array}{l}\text { Wiley Online Library: } \\
\text { onlinelibrary.wiley.com/ }\end{array}$ & $\begin{array}{l}\text { Wiley Online Library hosts a multidisciplinary collection of online } \\
\text { resources, with integrated access to over } 4 \text { million articles from } 1500 \\
\text { journals. }\end{array}$ \\
\hline
\end{tabular}


Table 3: (Continued...) Some suggested sources of information for educational research. These include resources categorised under the following: (1) educational databases and collections of abstracts, (2) educational publishers and general links, (3) evidence gathering and systematic reviews, (4) general publishers and search software vendors, and (5) miscellaneous resources and grey literature resources. Note that this list is by no means exhaustive. (Links accessed 2012.)

\begin{tabular}{|c|c|}
\hline \multicolumn{2}{|c|}{ Miscellaneous Resources and Grey Literature Sources: } \\
\hline $\begin{array}{l}\text { Advanced Google Scholar Search: } \\
\text { scholar.google.com/advanced_scholar_search }\end{array}$ & $\begin{array}{l}\text { A search tool that is focussed on academic literature and includes } \\
\text { sources such as: peer reviewed papers, theses, books, and abstracts. } \\
\text { The tool also provides citation statistics for papers and academic } \\
\text { items. }\end{array}$ \\
\hline $\begin{array}{l}\text { Education Counts: } \\
\text { www.educationcounts.govt.nz/ }\end{array}$ & $\begin{array}{l}\text { Based in New Zealand, Education Counts offers educational statistics } \\
\text { at school and tertiary levels. }\end{array}$ \\
\hline $\begin{array}{l}\text { Index to Theses: } \\
\text { www.theses.com/ }\end{array}$ & $\begin{array}{l}\text { A subscription resource, this provides a list of theses titles and } \\
\text { abstracts awarded by British and Irish institutions. }\end{array}$ \\
\hline $\begin{array}{l}\text { Organisation for Economic Cooperation and } \\
\text { Development (OECD) Online Education } \\
\text { Database: } \\
\text { www.oecd.org/education/database }\end{array}$ & $\begin{array}{l}\text { This is a statistical database that provides information on various } \\
\text { aspects of educational delivery and student characteristics. }\end{array}$ \\
\hline $\begin{array}{l}\text { ProQuest Digital Dissertations and Theses (link } \\
\text { from institutional gateway provider) }\end{array}$ & $\begin{array}{l}\text { This is an international searchable database of citations to } \\
\text { dissertations and theses from } 1861 \text { to the present day, with some full } \\
\text { text dissertations available for downloading. }\end{array}$ \\
\hline $\begin{array}{l}\text { System for Information on Grey Literature in } \\
\text { Europe (SIGLE): } \\
\text { www.opengrey.eu/ }\end{array}$ & $\begin{array}{l}\text { The System for Information on Grey Literature in Europe (SIGLE) is } \\
\text { an open access bibliographical database, that includes technical and } \\
\text { research reports, conference papers, official publications and other } \\
\text { grey literature. }\end{array}$ \\
\hline $\begin{array}{l}\text { The National Statistics Office: } \\
\text { www.statistics.gov.uk }\end{array}$ & $\begin{array}{l}\text { The National Statistics Office is the UK based governmental statistical } \\
\text { service, for a variety of themes, including that of education. }\end{array}$ \\
\hline $\begin{array}{l}\text { United Nations Educational, Scientific and } \\
\text { Cultural Organization (UNESCO) Institute for } \\
\text { Statistics: } \\
\text { stats.uis.unesco.org/unesco/tableviewer/ } \\
\text { document.aspx?Reportld=143 }\end{array}$ & $\begin{array}{l}\text { A database of statistical tables, that include data from the educational, } \\
\text { scientific and technological fields. }\end{array}$ \\
\hline
\end{tabular}

\section{Conducting the search and devising the search strategy}

Having narrowed and defined the research question, the specific variables can then be defined: scope of the literature search, inclusion/exclusion criteria, time periods, databases to use and any other variables. In addition, specific searches can be carried out within specified physical sciences journals $\left(\right.$ Table $5^{29}$ ). It is also useful to keep in mind how the review will be published and disseminated.
The appropriate selection of keywords and subject headings (including the use of synonyms) are paramount to an effective database search. As well as the ability to undertake free keyword searches, most databases will support more advanced requirements, including that of the ability to limit resource type (e.g. review or primary search article). Table 4 displays the most common operators and symbols used in filtering literature searches, however it is important to note that databases may vary in their specific use of symbols. 
Table 4: Search filtering strategies for database searching (may be database specific). Databases may also specify certain operators, for example, searching for adjacent terms or for specific keywords in titles. Some databases will also be able to support advanced searching through a combination of any of the terms through parenthesis bracketing (to preserve the original search logic).

\begin{tabular}{|c|c|}
\hline General Description & Symbols, Terms and Examples \\
\hline $\begin{array}{l}\text { Truncation is the term given to searching part of a word } \\
\text { that also searches similar words (simultaneously). } \\
\text { This technique also supports the searching of results that } \\
\text { are not limited to geographical location - e.g. due to the } \\
\text { variation of British and American English spelling. Also } \\
\text { consider the differences between layman terms and } \\
\text { formal terms, and old and new terminologies. }\end{array}$ & $\begin{array}{l}\text { * } \$ \text { ? } \\
\text { (Check each database for specific symbol usage) } \\
\text { Examples: } \\
\text { Phys* will find physical, physicist, physics, etc. } \\
\text { Colo*r will find colour or color. } \\
\text { ? is commonly used for substitution } \\
\text { Example: } \\
\text { wom?n will yield results of women and woman. }\end{array}$ \\
\hline $\begin{array}{l}\text { Combinations instruct searches to combine the defined } \\
\text { terms. } \\
\text { This technique also supports the searching of results that } \\
\text { are not limited to geographical location - e.g. due to the } \\
\text { variation of British and American English spelling. Also } \\
\text { consider the differences between layman terms and } \\
\text { formal terms, and old and new terminologies. }\end{array}$ & $\begin{array}{l}\text { AND - this will result in more specific searches } \\
\text { OR - this instructs a broader search } \\
\text { NOT - this excludes certain words. This should be used with } \\
\text { caution, as important studies may inadvertently be omitted. } \\
\text { Examples: } \\
\text { Physical AND Sciences } \\
\text { Physics Education OR Chemistry Education } \\
\text { STEM Education NOT General Education }\end{array}$ \\
\hline
\end{tabular}

Once again, record keeping is important for backtracking references and the ongoing summarisation of information is important for gathering and critiquing evidence for the review. In addition, this is perhaps the most likely stage to initiate the production of an annotated bibliography (or to simply highlight citations that could be used for one in the future). This stage may be iterative in nature and will usually be revisited at a later phase when the project outcomes have become clearer.

Having obtained all the relevant literature and having scanned articles, the search phase will be closed and the review writing will begin. It may also be evident when findings have reached saturation and judgement in revisiting the original search strategy may be required here. For some (e.g. PhD students) the literature search and review process may be more of an ongoing discovery process which supports the identification and writing up of arguments throughout the period of study.

\section{Synthesising, evaluating and appraising the literature}

Synthesising the evidence may be time consuming, but it is essential to ensure that writing and summarising information is an ongoing feature, for this will help 'slotting' essential arguments into key headings and themes. At this stage the theoretical framework (and thus review headings) will be much more refined and clarified.

In finalising the review, the following broad headings are commonly used: Introduction, search methodology, discussion and conclusion. The conclusion should answer the 'so what' question and should offer a clear way forward for the research journey to proceed or to provide information points on effective practice. Ultimately, this will depend on the initial motive for conducting the work. Whilst the review may be part of a wider research study, it can also be readily tweaked for publication into one of the various publications within the physical sciences. Some suggested journals and publication outlets are listed in the following table (Table 5). 
Table 5: Major journal titles that disseminate educational and pedagogical research within chemistry, physics and the physical sciences. Note that this list is by no means exhaustive. (Links accessed 2012.)

Journal and URL

New Directions

www.heacademy.ac.uk/journals/new-directions
Description

Published by the Higher Education Academy, this publication aims to disseminate the interim outcomes of new approaches and innovations in teaching the physical sciences. Includes communications and review articles.

Chemistry Education

\section{Education in Chemistry}

www.rsc.org/education/eic/

Chemistry Education Research and Practice

pubs.rsc.org/en/journals/journalissues/rp

Journal of Chemical Education

pubs.acs.org/journal/jceda8

A magazine published by the Royal Society of Chemistry and includes articles on practice, features, news and reviews.

Online journal published by the Royal Society of Chemistry, and publishes papers on research and practice, predominantly at the tertiary level.

The journal of the American Chemical Society. Publishes predominantly secondary articles on practice, laboratory experiments and reviews.

Physics Education

\section{European Journal of Physics}

www.iop.org/EJ/journal/EJP

\section{Physics Education}

www.iop.org/EJ/Journal/PhysEd

Physical Review Special Topics - Physics Education Research

prst-per.aps.org/

The Physics Teacher

www.thephysicsteacher.ie

\section{Aimed at physics teachers at the tertiary level. Issues contain laboratory exercises, reports on physics curricula, practice of} teaching physics, and cultural and historical aspects of physics.

Published by the Institute of Physics, this publication covers secondary and tertiary level physics teaching. Content is varied and includes practice, experiments, articles and features.

Free electronic journal sponsored by The American Physical Society (APS), the American Association of Physics Teachers (AAPT) and the APS Forum on Education (APS Fed). Covers experimental and theoretical research on the teaching and/or learning of physics at secondary and tertiary level.

Online and print journal published by the AAPT, it includes papers on physics research, the history and philosophy of physics, curriculum developments, pedagogy and book reviews.
International Journal of Science Education

www.tandf.co.uk/journals/tf/09500693.html

Journal of Research in Science Teaching

onlinelibrary. wiley.com/journal/10.1002/(ISSN)10982736

\section{Research in Science Education}

www.springer.com/education/science-education/ journal/11165

Research in Science and Technological Education www.tandf.co.uk/journals/carfax/02635143.html

\section{Science Education}

onlinelibrary.wiley.com/journal/10.1002/(ISSN)1098$237 X$
International journal of research in science education with the emphasis on research applicable to practice. Main focus is on primary and secondary education although it includes some HE level papers. 18 issues are published per year.

Official journal of the National Association for Research in Science Teaching, and reports include investigations in: case study research approaches, position papers, policy perspectives, and critical reviews of the literature.

Publishes science education research, mainly at primary and secondary level but with some tertiary level studies. It is an international journal publishing and promoting scholarly science education research.

Publishes original research from science education and/or technological education. It also publishes on psychological, sociological and organisational aspects of science education. Mainly focuses on primary and secondary level but also contains significant tertiary level papers.

Publishes international trends in science curriculum, instruction, learning, policy and in the preparation of science teachers. 


\section{Conclusion}

As educators, we are committed to supervising our students and in carrying out educational research that impacts the learning and teaching processes. In supporting educational practice, such educational research supports us in understanding how learning and teaching processes can be improved, as well as understanding factors that attract and retain our students. Physical science graduates undertaking educational research for the first time will need to plan and organise an effective search of the literature on their chosen topic. This will not only help support overall course aims, it will also support reflective practice, skills development in research, strategy and policy development skills and ultimately the development of skills for lifelong learning.

\section{Appendix - Guidance Checklist}

The following checklist (Table 6) offers a summary of the literature reviewing process and of the onward journey.

\section{References}

1. Bartlett, S. and Burton, D. (2007) Researching education, in Introduction to Education Studies, S. Bartlett and D. Burton, Editors, Sage Publications: London. p. 30-58.

2. Verma, G. and Mallick, K. (1999) Researching Education: Perspectives and Techniques, London: Falmer Press.

3. Johnson, B. and Christensen, L. (2012) Educational Research: Quantitative, Qualitative, and Mixed Approaches, 4th ed. London: Sage Publications Ltd.

4. AHRC (2009), Definition of Research. Arts and Humanities Research Council: UK.

5. Australian Government (2012) Higher Education Research Data Collection: Specifications for the collection of 2011 Data: Australian Government: Department of Industry Innovation, Science, Research and Tertiary Education.

6. The Quality Assurance Agency for Higher Education (2011), Doctoral Degree Characteristics. QAA.

7. The Quality Assurance Agency for Higher Education (2012), UK Quality Code for Higher Education: Research Degrees. Draft for Consultation. QAA: Gloucester.

8. Banister, P., Burman, E., Parker, I., Taylor, M., and Tindall, C. (2003) Qualitative Methods in Psychology: A Research Guide, Maidenhead: Open University Press.

9. Sharp, J. (2012) Success with your Education Research Project, 2nd ed. Study Skills in Education. London: Learning Matters, Sage Publications Ltd.

10. McKenney, S. and Reeves, T.C. (2012) Conducting Educational Design Research, Abingdon, Oxon: Routledge.

11. El-Farargy, N. (2010) Evaluation of a chemistry curriculum intervention using the Perry model of intellectual development. Chemistry Education Research and Practice, 11 (2), 98-106.

12. Lemanski, T. and Overton, T. (2011), Primer: An Introduction to Qualitative Research. University of Hull: UK Physical Sciences Centre.

13. Oktay, J.S. (2012) Grounded Theory. Pocket Guides to Social Work Research Methods. Oxford: Oxford University Press.

14. Atkinson, P. and Hammersley, M. (2007) Ethnography: Principles in Practice, 3rd ed. Abingdon, Oxon: Routledge, Taylor and Francis Group.

15. Entwistle, N. (1997) Introduction: Phenomenography in Higher Education. Higher Education Research \& Development, 16 (2), 127-134.

16. Booth, S. (1997) On Phenomenography, Learning and Teaching. Higher Education Research \& Development, 16 (2), 135-158.
17. Madsen, A.M., Larson, A.M., Loschky, L.C., and Rebello, N.S. (2012) Differences in visual attention between those who correctly and incorrectly answer physics problems. Physical Review Special Topics - Physics Education Research, 8 (1), 010122.

18. Ayene, M., Kriek, J., and Damtie, B. (2011) Wave-particle duality and uncertainty principle: Phenomenographic categories of description of tertiary physics students' depictions. Physical Review Special Topics - Physics Education Research, 7 (2), 020113.

19. Andrews, M., Squire, C., and Tamboukou, M. (2009) eds. Doing Narrative Research. Sage Publications Ltd: London.

20. Creswell, J.W. and Plano Clark, V.L. (2011) Designing and Conducting Mixed Methods Research, 2nd ed. London: Sage Publications Inc.

21. Simon, H.A. (1954) Spurious Correlation: A Causal Interpretation. Journal of the American Statistical Association, 49 (267), 467-479.

22. Reed, L.E. (1998) Performing a Literature Review. in Frontiers in Education Conference. Tempe, Arizona.

23. Easterby-Smith, M., Thorpe, R., and Jackson, P. (2012) Management Research, 4th ed. London: Sage Publications Ltd.

24. Aina, L.O. (2000) Grey literature and library and information studies: a global perspective. International Journal on Grey Literature, 1 (4), 179-182.

25. Page, D. (2008) Systematic Literature Searching and the Bibliographic Database Haystack. The Electronic Journal of Business Research Methods, 6 (2), 171-180.

26. Jesson, J.K., Matheson, L., and Lacey, F.M. (2011) Doing Your Literature Review: Traditional and Systematic Techniques, London: Sage Publications Ltd.

27. Campbell Collaboration (2012) What is a systematic review? Available online: $<$ www.campbellcollaboration.org/ what_is_a_systematic_review/index.html >[Accessed: 27 May 2012].

28. ERIC (2012) Education Resources Information Center. Available online: <www.eric.ed.gov/> [Accessed: 27 May 2012].

29. Overton, T. (2011) Publications in learning and teaching in the physical sciences. UK Physical Sciences Centre Briefing Paper. Hull: UK Physical Sciences Centre. 
Table 6: This checklist aims to offer guidance on the literature reviewing process and potential ways forward for the research journey.

\section{Guidance}

1. Decide on the scope of research

Background information

International or UK perspective

Set up email journal alerts (direct publisher alerts or integrated service alerts, e.g. Zetoc through the British Library <zetoc.mimas.ac.uk/>)

2. Clearly stated research question

Why are the research questions important?

Develop argument

Literature review to clarify own field work

Identify gaps in the body of knowledge

3. Consider the type of review that will be written up

Narrative or systematic review

In reading resources, keep writing and summarising information

Record all information sourced

4. Identify keywords which describe the topic

Examine titles and abstracts for relevance

Check synonyms and terminologies across geography (e.g. British and American spelling variations)

Beware of false hits when truncating keywords

5. Consider sources of information and databases to use

Known journals

Databases

Multidisciplinary databases

News archives

Internet gateways from university library web pages

General internet search

6. Search strategy - filtering results

Date of publication

Type of material (e.g. book, journal, government report)

Language

Review type

7. Search strategy - combining search results

AND

OR

NOT

9. Evaluate the information received

Is it fit for purpose?

Critical reading skills

The grey literature

10. Organising references

Research citation management software

Email or save search results from databases

Annotated bibliography

11. Onward journey

Qualitative, quantitative or mixed method research study

Questionnaire design and ethical approval

Questionnaire piloting and final distribution

Focus groups, and one to one interviews

Analysis, results write up, discussion

Dissertation/thesis completion

Writing for publication 